\title{
Evidence for historic coastal high-energy wave impact (tsunami?) in North Wales, United Kingdom
}

\author{
Simon K. Haslett ${ }^{1^{*}}$ and Edward A. Bryant ${ }^{2}$ \\ 1. Quaternary Research Centre, Department of Geography, School of Science and the Environment, \\ Bath Spa University, Newton Park, Bath, BA2 9BN, UK \\ 2. Science Faculty Office, University of Wollongong, Wollongong, NSW 2522, Australia \\ *corresponding author:<s.haslett@bathspa.ac.uk>
}

Date received: 30 July 2007 Date accepted: 08 November 2007

\begin{abstract}
Understanding the contribution of high-energy events (e.g. storms, tsunami) to coastal evolution is currently much debated. Field investigations in North Wales on Anglesey and the Lleyn Peninsula have identified four sites where imbricated boulder trains occur that are discriminators of wave characteristics. Clast analysis indicates that storm wave heights (ca. $20 \mathrm{~m})$, in excess of known extremes $(5$ to $<9 \mathrm{~m})$, are required to transport them. A plausible explanation is the historic impact of tsunami ( $\geq 5 \mathrm{~m}$ high) that may have been caused either by a) a submarine slide situated offshore on the edge of the continental shelf or Rockall Trough, b) through seismic activity, as the region is one of the most seismically active regions of the British Isles, or c) impact of comet debris in the North Atlantic, with a candidate event around $\mathrm{AD} 1014$. Field evidence suggests that such a high wave-energy event has not recurred along this coast within the last 400 years.

\section{RÉSUMÉ}

L'interprétation de la contribution des phénomènes de haute énergie (p. ex. tempêtes, tsunamis) à l'évolution des côtes fait présentement l'objet de beaucoup de débats. Des études sur le terrain dans le Nord du pays de Galles sur l'île d'Anglesey et sur la presqu'île de Lleyn ont défini quatre emplacements qui présentent des traînées de blocs rocheux constituant des discriminateurs des caractéristiques des vagues. Une analyse des clastes révèle qu'il faut des hauteurs de vagues de tempête (environ $20 \mathrm{~m}$ ), supérieures aux extrêmes connus (5 à moins de $9 \mathrm{~m}$ ), pour les transporter. Une explication plausible réside dans l'incidence historique des tsunamis ( $\geq 5 \mathrm{~m}$ de hauteur) ayant pu être causés a) par un glissement sous-marin au large de la bordure de la plate-forme continentale ou de la dépression Rockall, b) par l'activité sismique, car la région constitue l'une des régions les plus actives des îles Britanniques sur le plan sismique ou c) par l'incidence de débris de comète dans l'Atlantique nord, un événement candidat étant survenu vers 1014 de notre ère. Des indices sur le terrain laissent supposer qu'aucun phénomène de haute énergie de vagues de ce genre ne s'est reproduit le long de cette côte au cours des 400 dernières années.
\end{abstract}

[Traduit par la redaction]

\section{INTRODUCTION}

The Irish Sea coast of North Wales is relatively sheltered from the most severe Atlantic storms with extreme wave heights of 5 to $<9 \mathrm{~m}$ (Devoy 2000). However, physical evidence is present along the coast indicating higher wave energy activity than is suggested by the oceanographic setting. Studies examining high-energy wave activity in northwestern Europe are emerging, including examples in Scotland (Hansom 2001), western Ireland (Williams and Hall 2004), Bristol Channel (Bryant and Haslett 2007), and elsewhere in the region (Haslett and Bryant 2007), and signal a new appreciation of the importance of fully understanding the contribution made by high-magnitude, lowfrequency events (e.g., storms and tsunami) to coastal evolution (Haslett 2000). The present study contributes to this growing debate in the North Atlantic by presenting physical evidence of high-energy wave impact from North Wales.

\section{STUDY AREA AND METHOD}

Four sites are examined for evidence of high-energy wave activity; three on the southwest coast of Anglesey (Porth Cwyfan, Porth Terfyn, and Llanddwyn Island), and one on 
the northwest coast of the Lleyn Peninsula (Porth Dinllaen) in North Wales (Fig. 1). The geology of the area is characterized by Precambrian metasedimentary rocks, extrusive igneous rocks, and Quaternary glacial deposits (Smith 1961), which influence the topography and configuration of the coastline.

One of the most reliable, and most commonly used, morpho-sedimentological discriminators of wave characteristics is the occurrence of wave-transported boulders (Bourrouilh-Le Jan and Talandier 1985; Jones and Hunter 1992; Young et al. 1996; Bryant and Nott 2001; Scheffers 2002). Through the measurement of boulder dimensions, it is possible to estimate the minimum storm and tsunami wave height required to transport these clasts. These calculations have been developed through a series of studies that have refined precision (Nott 1997, 2003), but extensive calibration is yet to be fully achieved. To minimize any deficiency in precision, Bryant and Haslett (2007) presented a set of 10 criteria used to distinguish boulders transported by tsunami rather than storm waves. Used together, these methods allow minimum wave heights for boulder transport and the process responsible for their transport to be established at the sites investigated.

Boulders occur sporadically as isolated clasts and, more commonly, as sorted accumulations at various localities along the coast of the Lleyn Peninsula and Anglesey. Boulders were examined at four locations (Fig. 1) where field criteria indicate that they had been transported by wave activity (not glacially deposited), usually arranged as imbricated boulder trains. Measurements were made of boulder dimensions comprising $\mathrm{a}$ (longest), $\mathrm{b}$ (intermediate) and c (shortest) axes. If imbricated, the direction of imbrication was recorded, as was the present position of the boulder in relation to the tidal frame. This position was achieved through the use of lichen zonation (Cremona 1988; Haslett and Curr 1998; Haslett 2000; Bryant and Haslett 2007), with orange lichen (Xanthoria parietina) indicating a position within the splash zone above Highest Astronomical Tide (HAT), black lichen (Verrucaria maura) indicating a position on the upper shore between HAT and Mean High Water Spring Tide (MHWST), and boulders barren of lichen indicating a present position on the middle shore equivalent to Mean High Water (MHW). At each location a number of large boulders were measured. These data were used to estimate the range in wave height required to transport them by both tsunami $\left(\mathrm{H}_{\mathrm{t}}\right)$ and storm $\left(\mathrm{H}_{\text {storm }}\right)$ waves following the procedure for the transport of sub-aerial, submerged and joint bound boulders by Nott (2003; see also Bryant and Haslett 2007).

\section{RESULTS}

The results for the largest boulders at each site are listed in Table 1 . These data represent the minimum storm $\left(\mathrm{H}_{\text {storm }}\right)$ and tsunami $\left(\mathrm{H}_{\mathrm{t}}\right)$ wave height required to move these boulders depending on whether the boulders were lying subaerially at the time of wave-entrainment (low end of range), having already been quarried from bedrock, or joint bound and excavated and transported by the wave event (high end of range).

At Porth Cwyfan an embayment is eroded into an unconsolidated till-filled glacial valley cut into Precambrian

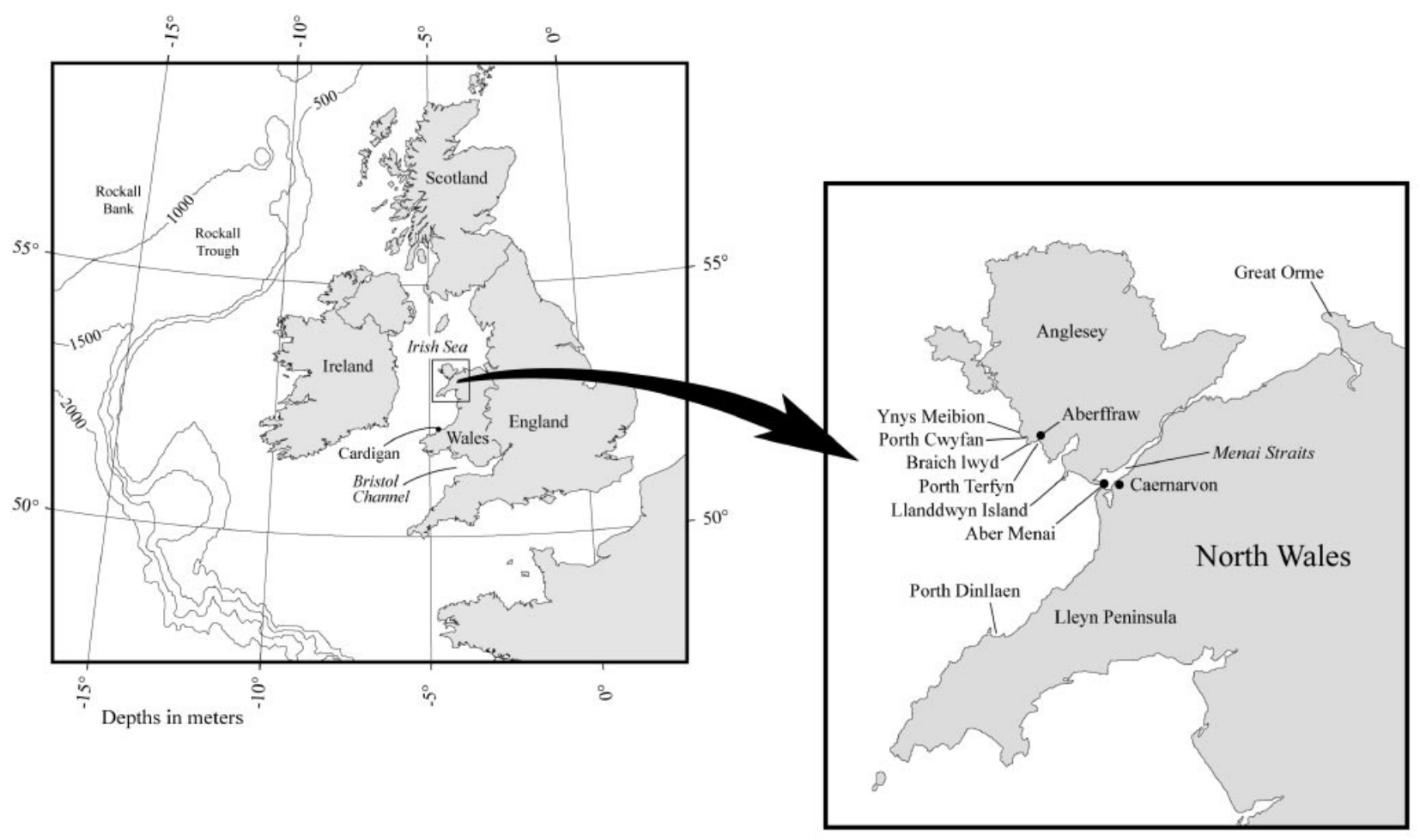

Fig. 1 Location of the study sites on Anglesey and the Lleyn Peninsula, North Wales, within a regional context. 
metasediment (Fig. 1). The till contains boulder-sized clasts up to approximately a $1 \mathrm{~m}$ maximum diameter. The $12-13^{\text {th }}$ century St. Cwyfan's Church has been constructed on the till, the erosion of which has since left the church stranded in the middle of the bay, $246 \mathrm{~m}$ from the present cliffline, on an island of till now artificially protected by stone sea walls and underlain by a rock platform. A local $17^{\text {th }}$ century map shows the line of the till cliffs seaward of the church, so that the evolution of the bay and the creation of the island has occurred subsequently. From this it is possible to estimate the retreat rate of the till cliffs at $0.615-0.820 \mathrm{~m} /$ year.

Two imbricated boulder trains, comprising angular clasts, lie on the upper part of the rock platform at Porth Cwyfan, approximately at the level of HAT, and about $150 \mathrm{~m}$ seaward of the church (Figs $2 \mathrm{a}, \mathrm{b}$ ). The largest boulder indicates an $\mathrm{H}_{\text {storm }}$ of 3.8-25.8 $\mathrm{m}_{\text {and }} \mathrm{H}_{\mathrm{t}}$ of $0.9-6.4 \mathrm{~m}$ (Table 1). Interestingly, in the bay, landward of the island, smaller boulders released from the erosion of the till remain as a lag of scattered isolated clasts on the rock platform and do not appear to have been transported and accumulated into piles by waves (Fig. 2c). Appreciating wave dissipation effects and the smaller size of these boulders, it suggests that a wave impact event of sufficient magnitude to move these small boulders has not occurred within the last 400 years or so and that the two imbricated boulder trains that occur seaward of the church are likely to have been transported and deposited by an older event. Indeed, if the historic till erosion rates are extrapolated the wave event may be estimated to have occurred before or during the period AD 1356-1517, but certainly before the end of the $17^{\text {th }}$ century.

Porth Terfyn is a small embayment located about $1.5 \mathrm{~km}$ from Porth Cwyfan on the southeast side of the headland, Braich-lwyd, that separates the two (Fig. 1). It contrasts with Porth Cwyfan in that it is an entirely hard rock setting with a narrow rock platform backed by up to $10 \mathrm{~m}$ high rock cliffs with no evidence of significant retreat, although isolated small-boulder clasts from rock fall are seen to litter the platform in places. Two imbricated boulder trains ascend the tidal frame (Fig. 2d) with the largest boulder indicating an $\mathrm{H}_{\text {storm }}$ of $19.9-35.0 \mathrm{~m}$ and $\mathrm{H}_{\mathrm{t}}$ of 5.0-8.8 $\mathrm{m}$ (Table 1). Although there is no way of dating the emplacement of the boulders here, the occurrence of isolated smaller boulders on the platform, apparently from rock fall, suggests that the imbricated boulder trains were deposited sometime ago.

Llanddwyn Island is located about $5 \mathrm{~km}$ southeast along the coast from Porth Terfyn, and is an elongate rocky (basalt) peninsula orientated NNE-SSW (Figure 1). Rocky cliffs rise to approximately $10 \mathrm{~m}$ fringed by narrow rock platforms. Towards the NNE end of the peninsula, sandy bays occur between rocky headlands. A number of imbricated boulder trains, that ascend the tidal frame, occur on the southwest tip of the peninsula, northwest of the light house (Fig. 3a, b). The largest boulder indicates an $\mathrm{H}_{\text {storm }}$ of 18.4-25.2 $\mathrm{m}$ and $\mathrm{H}_{\mathrm{t}}$ of 4.6-6.3 m (Table 1).

Porth Dinllaen is located on the northwest coast of the Lleyn Peninsula, and is itself a north-south orientated rocky (basalt) peninsula just over $1 \mathrm{~km}$ long fringed by rocky cliffs 
a
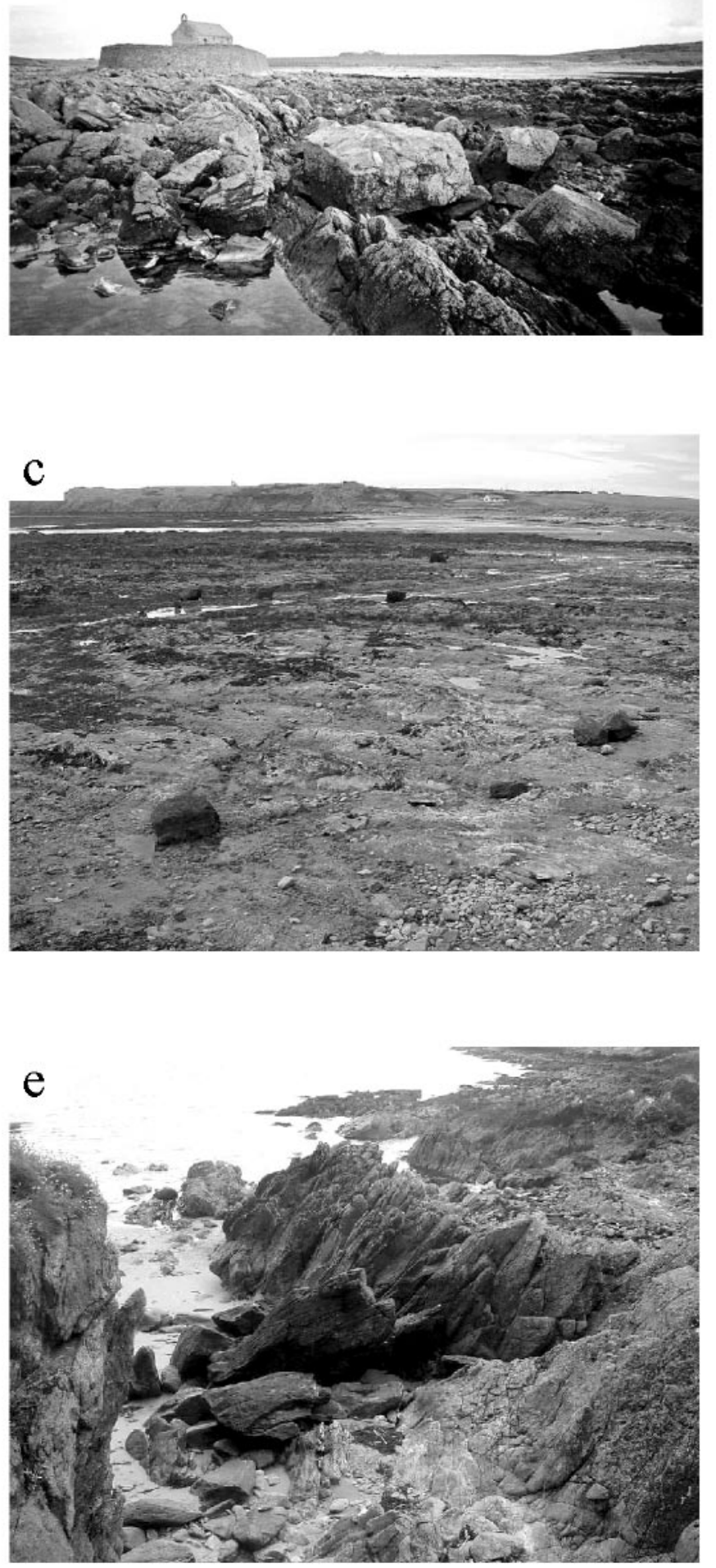
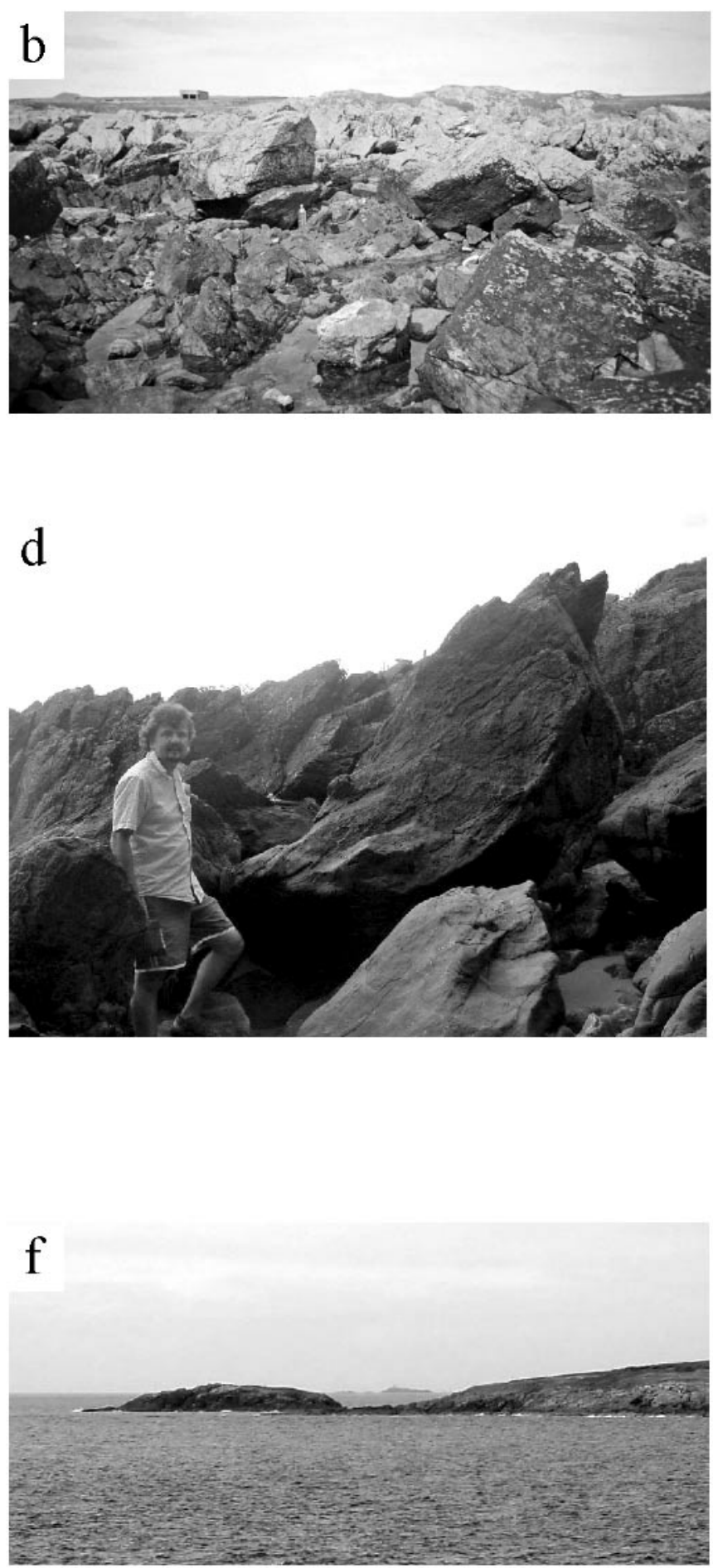

Fig. 2 Photos a) imbricated boulders and church at Porth Cwyfan, b) imbricated boulders at Porth Cwyfan, c) boulder lag on platform from the retreat of glacial till cliffs at Porth Cwyfan, d) a large imbricated boulder at Porth Terfyn, e) imbricated boulder train ascending the tidal frame at Porth Terfyn (the large boulder shown in $2 \mathrm{~d}$ is located in the centre of the photograph), f) tooth-brush headland of Ynys Meibion west of Porth Cwyfan. Scale: $a, b$ ) water bottle $=0.3 \mathrm{~m}$ long. 

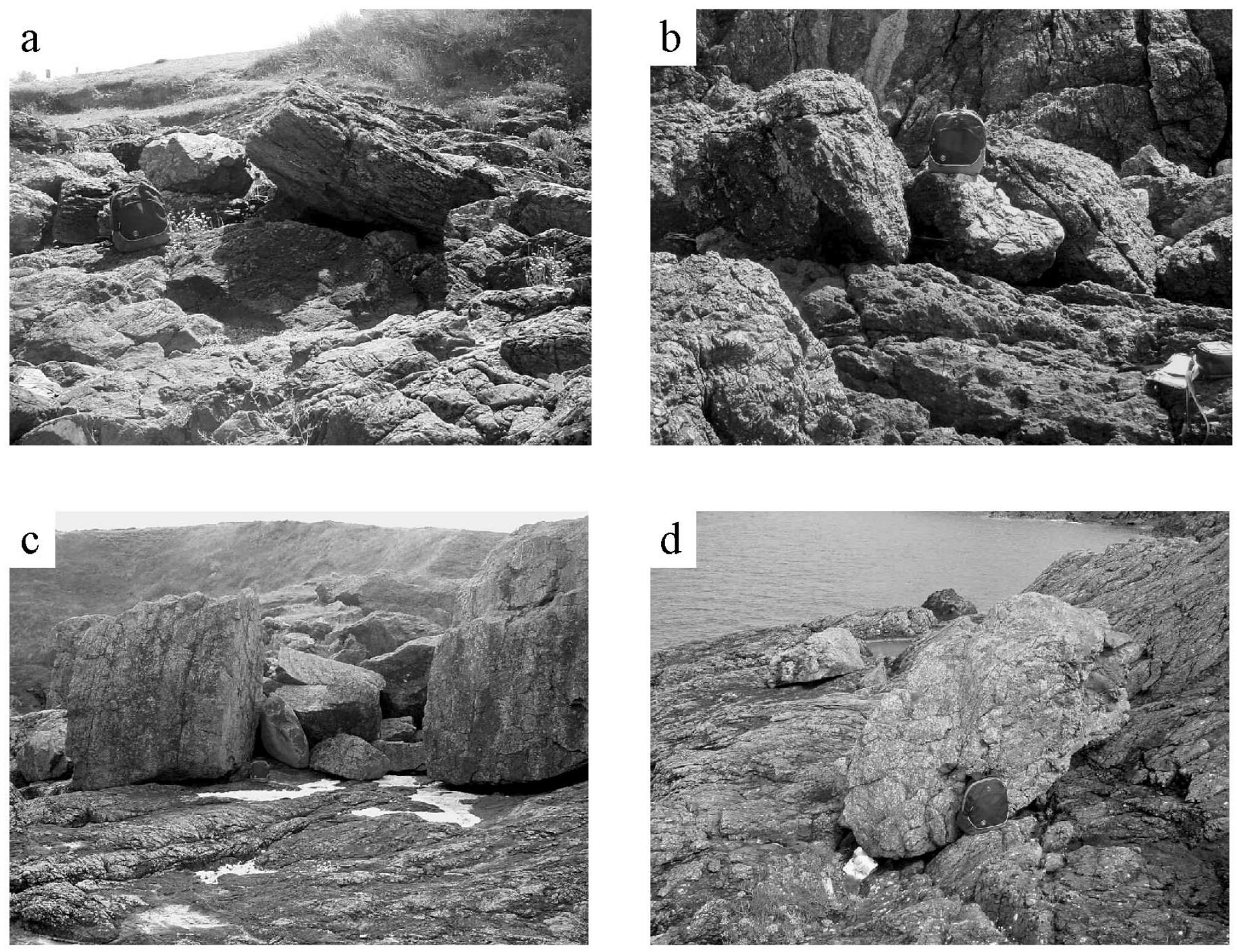

Fig. 3 Photos a) imbricated boulder at the high tide limit at Llanddwyn Island b) an imbricated boulder train at Llanddwyn Island, c) imbricated boulder train at Porth Dinllaen, d) scattered boulders at Porth Dinllaen. Scale: back-pack =0.4 m high.

and a narrow platform. Boulder trains and associated large isolated boulders occur up to and above HAT on the northern tip and on the west shore of the peninsula (Figs. 3c, d) with the largest indicating an $\mathrm{H}_{\text {storm }}$ of 12.7-53.7 $\mathrm{m}$ and $\mathrm{H}_{\mathrm{t}}$ of 3.2-13.4 $\mathrm{m}$ (Table 1).

\section{DISCUSSION}

Figure 4 compares the range in wave heights required to transport the imbricated boulders analysed here from four coastal sites in North Wales. The largest boulders at three of the sites appear to require wave heights in excess of the Irish Sea extreme storm wave heights (Devoy 2000). Indeed, as these figures represent the minimum wave height required to move a boulder, the boulder offering the most resistance to transport, at Porth Terfyn, provides a minimum wave height for the entire data set at $\mathrm{H}_{\text {storm }}=19.9 \mathrm{~m}$. Table 2 evaluates tsu- nami as a process accounting for the boulder deposits based upon ten criteria identified elsewhere as linked to this process (Bryant and Haslett 2007), against which the sites score highly. It appears from these data that either our understanding of historic storm wave heights for the Irish Sea is deficient, or that a contribution from other wave phenomenon, such as tsunami, requires consideration.

Tsunami are not generally considered to have affected the coast of the British Isles to any great extent (Long and Wilson 2007), with the notable exceptions of the prehistoric Storegga submarine slide-triggered tsunami (Smith et al. 2004) and the 1755 tsunami generated by the Lisbon earthquake (Foster $e t$ al. 1991; Dawson et al. 2000). However, the Storegga event is considered to have only affected the northeast coast of Great Britain. While the 1755 tsunami is known to have hit the coast of southwest England, South Wales, and southern Ireland, the wave height is not thought to have exceeded 2-3 $\mathrm{m}$ at these locations. 


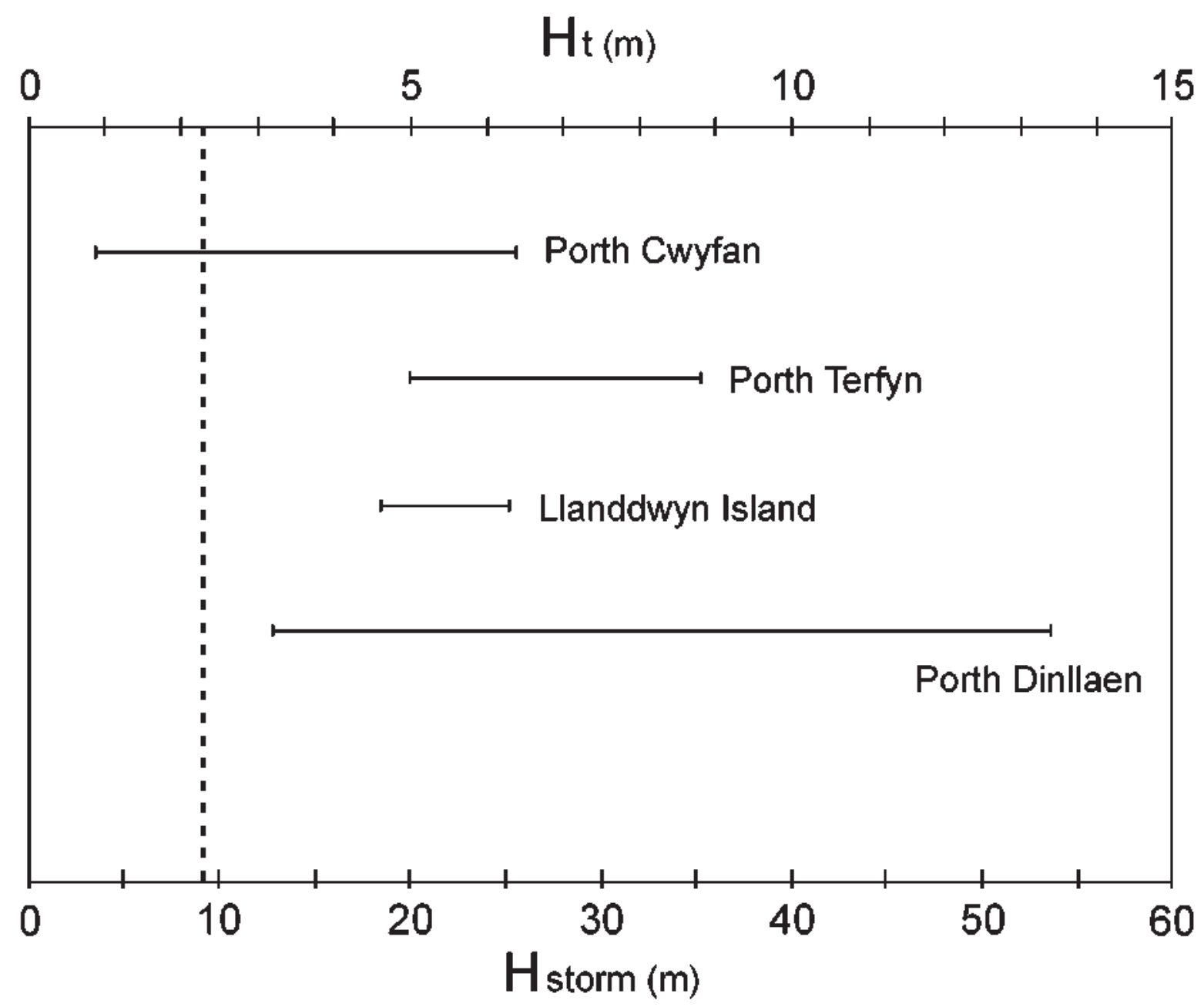

Fig. 4 Comparison of tsunami $\left(\mathrm{H}_{\mathrm{t}}\right)$ and storm $\left(\mathrm{H}_{\text {storm }}\right)$ wave heights $(\mathrm{m})$ required to transport boulders measured at the four study sites in North Wales; the level of extreme storm wave heights for the Irish Sea (Devoy 2000) is indicated.

Table 2. Assessment and scoring of boulder occurrences in North Wales, against a suite of characteristics that help to distinguish transport by tsunami from storm waves (see text for discussion).

\begin{tabular}{|c|c|c|c|c|c|c|}
\hline & $\begin{array}{l}\text { Characteristic of tsunami } \\
\text { transported boulders }\end{array}$ & $\begin{array}{l}\text { Porth } \\
\text { Cwyfan }\end{array}$ & $\begin{array}{l}\text { Porth } \\
\text { Terfyn }\end{array}$ & $\begin{array}{l}\text { Llanddwyn } \\
\text { Island }\end{array}$ & $\begin{array}{c}\text { Porth } \\
\text { Dinllaen }\end{array}$ & $\begin{array}{l}\text { Number of sites showing } \\
\text { characteristic (out of } 4 \text { ) }\end{array}$ \\
\hline 1 & deposited in groups & $\mathrm{X}$ & $\mathrm{X}$ & $\mathrm{X}$ & $\mathrm{X}$ & 4 \\
\hline 2 & only boulders & $\mathrm{X}$ & $\mathrm{X}$ & $\mathrm{X}$ & $\mathrm{X}$ & 4 \\
\hline 3 & imbricated and contact-supported & $\mathrm{X}$ & $\mathrm{X}$ & $\mathrm{X}$ & $\mathrm{X}$ & 4 \\
\hline 4 & evidence of suspension transport & $\mathrm{X}$ & $\mathrm{X}$ & $\mathrm{X}$ & & 3 \\
\hline 5 & evidence of lateral transport & $\mathrm{X}$ & $\mathrm{X}$ & $\mathrm{X}$ & $\mathrm{X}$ & 4 \\
\hline 6 & above the storm wave limit & & & & & 0 \\
\hline 7 & not flicked by storm waves & $\mathrm{X}$ & $\mathrm{X}$ & $\mathrm{X}$ & $\mathrm{X}$ & 4 \\
\hline 8 & hydrodynamic determinations exclude storms & & $\mathrm{X}$ & $\mathrm{X}$ & $\mathrm{X}$ & 3 \\
\hline 9 & imbrication matches direction of tsunami & $\mathrm{X}$ & $\mathrm{X}$ & $\mathrm{X}$ & $\mathrm{X}$ & 4 \\
\hline \multirow[t]{2}{*}{10} & other nearby signatures of tsunami. & $\mathrm{X}$ & & & $\mathrm{X}$ & 2 \\
\hline & Total Number of characteristics (out of 10 ) & 8 & 8 & 8 & 8 & \\
\hline
\end{tabular}


More recently, Bryant and Haslett (2007) present physical evidence for tsunami impact in the Bristol Channel that they contest may have been the cause of a catastrophic flood that occurred in the region in 1607 (Bryant and Haslett 2003; Haslett and Bryant 2005). Their evidence suggests the possibility of a tsunami wave height up to $6 \mathrm{~m}$ in the Severn Estuary. Although, this event might be considered as an explanation for the evidence presented here for North Wales, the historical accounts indicate the 1607 flood did not affect the coast north of Cardigan (Fig. 1). Moreover, evidence from Porth Cwyfan suggests that the timing of the North Wales wave event(s) may be older than 1607.

Near Porth Cwyfan and Porth Terfyn (Fig. 1), Aberffraw has a dune field located immediately to the east that extends about $3 \mathrm{~km}$ inland. Bailey et al. (2001) dated the initial sand inundation here, which they consider to be storm emplaced, using optical stimulated luminescence (OSL). This dating suggests the sediment was last exposed to light before AD 1180-1460. Besides the chronological link, the significance of this is that extensive sand layers are the most common signature of tsunami (Bryant 2001) and that sufficient inland penetration, based on boulder data (Table 3), is possible.

Older historic records for the area exist in Welsh and often take the form of bardic poetry that, although written in a romantic style, recount contemporary events and the deeds of historical figures. Such media falls between the more factual type of historical account, such as the chap book pamphlets used by Bryant and Haslett (2003) and parish records consulted by Haslett and Bryant (2005), and myths and legends passed on through oral tradition (Bryant et al. 2007). A brief examination of these accounts reveals a number of poems from the $12^{\text {th }}$ century that are worthy of some consideration (Table 4). Gwalchmai wrote during the middle of the $12^{\text {th }}$ century and makes extensive reference to a "green wave" (Williams 1973). Although the writings of Gwalchmai are creative poems, like Homer's Iliad and Odyssey, they appear to contain sound geographical information, with a number of places mentioned and environmental observations given to set the scene. This attention to detail encourages a sense that the writings represent real events and that the use of the word "wave" is perhaps not a metaphor. A second poet, Hywel ab Owain Gwynedd, who was a contemporary of Gwalchmai and died in 1170 , also wrote a number of poems worth considering although his poems contain less detail than Gwalchmai and are more rhetorical, yet could recount an event that the two poets may have experienced in the area, that perhaps became part of the local folklore for a while. Although the nature of this media and the numerous possible readings of these poems makes any interpretation speculative, the description of an unusual wave with its associated phenomenon by two contemporary poets who lived in the area during the $12^{\text {th }}$ century might conceivably be relating a flood event that involved a large wave and occurred either during their lifetimes, or previously and subsequently known about through folklore.

Mechanisms for generating tsunami that may affect the Irish Sea coast of North Wales are likely to be local in origin, as a tsunami generated in the Atlantic is likely to have impacted other coastlines in western Europe and may be expected to be relatively well documented. This region of North Wales and the Irish Sea is one of the most seismically active areas in Great Britain with regular small to moderate earthquakes (Table 5). The largest earthquake recorded here occurred on $19^{\text {th }}$ July 1984 with a magnitude of $5.4 \mathrm{M}_{\mathrm{L}}$ (Turbitt et al. 1985) with an epicentre on the Lleyn Peninsula. Although this value is below the accepted magnitude threshold of around 7.5 for tsunami generation (Bryant 2001) it is not inconceivable that throughout history a larger earthquake of sufficient magnitude may have occurred. Also, it is possible for earthquakes of $<7.5$ to generate tsunami under certain conditions. For example, the National Geophysical Data Center (2007) tsunami database lists 11 earthquakes $\leq 6.0 \mathrm{M}_{\mathrm{L}}$ that generated tsunami $\geq$ $1.0 \mathrm{~m}$ high, with two 5.2 and $5.6 \mathrm{M}_{\mathrm{L}}$ earthquakes generating tsunami 6.1 and $6.0 \mathrm{~m}$ high in California and New Zealand respectively. Indeed, the May 1842 Caernarvon earthquake (unknown magnitude) affected two ships crossing a sand bar in Caernarvon Harbour when the crews reported a "trembling of the vessels as if they had struck the ground" (Davison 1924, p. 172). If the fetch direction of the wave is traced offshore, as indicated by the mean imbrication of all measured boulders at the four sites (Table 3 ), convergence occurs approximately $15 \mathrm{~km}$ from the coast of the Lleyn Peninsula, around $4^{\circ} 50^{\prime} \mathrm{W}$

Table 3. Maximum velocity, maximum distance inland and flow direction of tsunami inferred from boulders at various sites around North Wales.

\begin{tabular}{cccccc}
\hline Area & Site & $\operatorname{Vr}\left(\mathrm{m} \mathrm{s}^{-1}\right)$ & $\begin{array}{c}\text { Penetration } \\
\text { Inland }(\mathrm{km})\end{array}$ & $\begin{array}{c}\text { Fetch } \\
\text { direction }\end{array}$ & $\begin{array}{c}\text { Mean orientation of } \\
\text { imbricated boulders }\end{array}$ \\
\hline Anglesey & Porth Cwyfan & $6.1-15.9$ & $0.4-4.7$ & $227^{\circ} \mathrm{SW}$ & $225^{\circ}$ \\
Anglesey & Porth Terfyn & $14.0-18.5$ & $3.4-7.1$ & $194^{\circ} \mathrm{SSW}$ & $223^{\circ}$ \\
Anglesey & Llanddwyn Island & $13.4-15.7$ & $3.0-4.6$ & $198^{\circ} \mathrm{SSW}$ & $235^{\circ}$ \\
Lleyn Peninsula & Porth Dinllaen & $11.1-22.9$ & $1.8-12.6$ & $282^{\circ} \mathrm{WNW}$ & $275^{\circ}$ \\
\hline
\end{tabular}

$\operatorname{Vr}\left(\mathrm{m} \mathrm{s}^{-1}\right)=$ tsunami run-up velocity 
Table 4. Extracts from $12^{\text {th }}$ century Welsh poems.

Extract
"The green wave by Aberffraw woke me, it strikes at
the land, it bears riches, bravely the birds sing
around it." (Gwalchmai Exultation, Williams 1973,
p. 34)
"The green wave at Aber Dau woke me, it strikes the
grey shore with its fair streams, bravely the birds sing
there; a place for my enemies to retreat from."
(Gwalchmai Exultation, Williams 1973, p. 34)

"Early summer is pleasant, the weather fine, the lovely, happy summer gently lingers; the waters gently gather, the turflaughs by the running water of Ogwen, Cegin and Clywedog streams. The sea wave with its great roar woke me steadily flowing from Aber Menai; the white waves pound under the Great Orme, the seashore of Lord Maelgwyn's maidens." (Gwalchmai Exultation, Williams 1973, p. 35)

"A foaming white wave washes over a grave ... where the seas reach in long contention.... A white wave, near the homesteads, foams over, coloured like hoarfrost in the hour of it's advance." (Hywel ab Owain Gwynedd Exultation, Williams 1973, p. 36)

"The wave's topped with foam, there is swift saddling;" (Hywel ab Owain Gwynedd Ode I, Williams 1973, p. 39). "Bright and shining it rises from the ocean shore” (Hywel ab Owain Gwynedd Ode II , Williams 1973, p. 40). "... the wave ... a flowing from her domain had come to us," (Hywel ab Owain Gwynedd Ode V, Williams 1973, p. 43).
This passage introduces a wave that struck the coast at Aberffraw, very close to the sites of Porth Cwyfan and Porth Terfyn (Fig.1). The reference to colour may signify the wave was unusual, and it is important that the passage refers to a single wave and that it made an obvious impact. It may be perceived to bear riches if it washed resources onto the land, such as fish, seaweed, or sediment. for example.

The passage again refers to a single green wave at a second location and again it makes an obvious impact on the shore. "A place for my enemies to retreat from" might perhaps refer to the wave being violent and destructive. (Aber Dau simply means two estuaries, but is unlikely to be Aber Dau Gleddau (Milford Haven in southwest Wales) as the towns first mention is in 1191 (Owen, 2000). 21 vears after Gwalchmai’s death.)

This suggests the timing and meteorological conditions of the scene. Early summer, fine weather, and idyllic conditions, yet a singular loud sea wave (which tends to refute any metaphorical use of the word "wave") is related to another location. The reference to waves (plural) pounding under the Great Orme may be a digression, or an attempt to liken the sea wave at Aber Menai with the poet's previous experience with large waves, perhaps to find an analogy.

Again, a singular wave with a distinct colour that "washes over a grave" (perhaps indicating fatalities). The second and third lines here might suggest that the wave penetrated inland beyond normal limits and threatened dwellings. The reference to foam and the wave appearing like hoar-frost implies a frothy-sparkling appearance that is very reminiscent of eye-witness accounts of recent tsunami. The reference to the "the hour of it's advance" doesn't only suggest that the wave struck rapidly, but is also reminiscent of tsunami advancing overland.

These extracts provide further reference to a singular foaming wave, and that it was either travelling at high velocity, or that people had to be quick to mount their horses to get out of the wave's path! "Bright and shining" is again reminiscent of some recent tsunami (Bryant 2001), and the use of the word "rises" might be a suggestion that the wave attained greater height than a normal wave. 
Table 5. Summary of known historic earthquakes around Anglesey and the Lleyn Peninsula, North Wales.

\begin{tabular}{|c|c|c|c|}
\hline Date & Location & $\begin{array}{l}\text { Magnitude } \\
\quad(\mathrm{ML})\end{array}$ & Reference \\
\hline 1782,5 th October & Caernarvon & & Davison (1924) \\
\hline 1818, 7th December & Caernarvon & & Davison (1924) \\
\hline 1827, 9th February & Lleyn Peninsula & 3.3 & BGS, Davison (1924) \\
\hline 1827,17 th March & Bardsey Island & & Davison (1924) \\
\hline 1842, early May & Caernarvon & & Davison (1924) \\
\hline 1842,22 nd August & Caernarvon & & Davison (1924) \\
\hline 1852, 9th November & Irish Sea & $5.4 ?$ & Musson et al.(1986) \\
\hline 1903, 19-29th June & Caernarvon & & Davison (1924) \\
\hline 1984, 19th July & Lleyn Peninsula & 5.4 & Turbitt et al. (1985) \\
\hline 1992, 29th July & Caernarvon & 3.5 & British Geological Survey (2001) \\
\hline 1994, 10th February & Bangor & 2.9 & British Geological Survey (2001) \\
\hline 1998,16 th October & Port Dinorwic & 2.7 & British Geological Survey (2001) \\
\hline 1999,1 st September & Caernarvon & 3.2 & British Geological Survey (2001) \\
\hline 2000,22 nd June & Lleyn Peninsula & 2.6 & British Geological Survey (2001) \\
\hline
\end{tabular}

$52^{\circ} 57^{\prime} \mathrm{N}$, close to the offshore extension of the Menai Straits Fault System (Turbitt et al. 1984).

Submarine slides may also be a possibility, although the Irish Sea does not seem a good candidate for slide generation. However, the continental shelf and slope offshore Ireland is considered to offer the potential to generate tsunami and has recently been briefly considered by Kerridge (2005) who identifies slope failures in the Rockall Trough as possibly tsunamigenic, posing a threat to southwest Britain and western Scotland. What must also be considered is the fact that similar slopes in the North Atlantic have produced tsunami. Most notable was the Burin Peninsula, Newfoundland tsunami event of 18 November 1929 (Heezen and Ewing 1952; Piper et al. 1999). The tsunami was produced by a submarine landslide or slump triggered by an earthquake with a surface wave magnitude of 7.2. Numerous, shallow, submarine slides occurred in a 120 - to $260-\mathrm{km}$-wide swathe over a distance of $110 \mathrm{~km}$ along the slopes of the continental shelf. These slides coalesced over several hours into debris flows and then one of the biggest turbidity currents yet identified either historically or geologically. The resulting tsunami reached a maximum run-up of $13 \mathrm{~m}$ above sea level at St. Lawrence on the Burin Peninsula $150 \mathrm{~km}$ from the earthquake epicentre. The tsunami was not restricted to Newfoundland. It measured $0.5 \mathrm{~m}$ high at Halifax and registered on tide gauges as far away as South Carolina and Portugal, although no damage was reported. The event is considered rare for this part of the North American Coast, with a recurrence interval of 1000-35 000 years (Bryant 2001). However, a similar, but smaller, event occurred in the same region in 1884. Since European settlement in North America, three other large earthquakes along the East Coast could have generated tsunami if they had happened at sea or triggered submarine landslides. These events occurred at Cape Anne, Massachusetts, in 1755; Charleston, South Carolina, in 1886; and Baffin Bay in 1934 (Bryant 2001).

Alternatively, a tsunami may be caused by the impact of a comet and/or comet debris in the sea. The recently formed Holocene Impact Working Group is highlighting the possibility that comet impacts have occurred every 1000 years or so throughout the Holocene and in some cases generated megatsunami (see Blakeslee 2006). Some authors consider comet sightings and impacts to be prevalent in Celtic myths and legends in Ireland and elsewhere, and link them to some historic environmental catastrophies (McCafferty and Baillie 2005). Baillie $(2006,2007)$ cites ice core data that show an anomalous peak in ammonium at $\mathrm{AD} 1014$ that he considers indicates a comet impact. This is supported in that the only other ammonium peak of similar size within the last 2000 years occurs in 1908 coincident with the Tunguska bollide impact over Siberia. Interestingly, the Anglo-Saxon Chronicle (Ingram 1823) and the accounts of William of Malmesbury (Mynors et al. 1998) both record an unusual marine inundation occurring in September 1014, affecting the south coast of Britain, and causing many fatalities, which may have been an associated tsunami. If this is the case, it is likely to have affected the Atlantic coast of Europe in general, including North Wales.

From this discussion, it appears that there are a number of possible candidates for tsunami impact in North Wales prior to 400 years ago, including AD 1014, the $12^{\text {th }}$ century, and 1607 , which may involve different tsunami triggers. However, regardless of the timing and mechanism, if we accept that the boulder evidence presented here indicates tsunami activity then other signatures of tsunami impact may be expected in the landscape. In addition to sand layer deposition, other common tsunami 
signatures include bedrock erosion (Bryant and Young 1996; Bryant 2001; Bryant and Haslett 2007). Although a systematic study of this coastline has not yet been made, some landforms, such as the tooth-brush headland of Ynys Meibion (Figs. 1, 2f), and calculated flow velocities from boulder data (Table 3) suggest tsunami bedrock erosion features may be present and require investigation.

\section{CONCLUSION}

Field investigations have identified imbricated boulder accumulations at four sites in North Wales. Measurements of boulder dimensions allow an estimation of wave height required to transport them. For the entire dataset, a minimum storm wave height of about $20 \mathrm{~m}$ is required, which is above extreme Irish Sea storm wave heights. Therefore, the possibility that the boulders here were transported by tsunami must be considered because tsunami wave heights of only $5 \mathrm{~m}$ are required. Field evidence suggests that the high wave energy event(s) occurred before the end of the $17^{\text {th }}$ century. This study has raised the possibility that tsunami have contributed to coastal evolution in North Wales and requires further investigation.

\section{ACKNOWLEDGEMENTS}

SKH is grateful to Bath Spa University for funding field work. The authors would like to thank the journal reviewers, Norm Catto and David Piper, for their constructive comments that have improved the manuscript.

\section{REFERENCES}

Bailey, S. D., Wintle, A. G., Duller, G. A. T., and Bristow, C. S. 2001. Sand deposition during the last millennium at Aberffraw, Anglesey, North Wales as determined by OSL dating of quartz. Quaternary Science Reviews, 20, pp. 701-704.

BAILLIE, M. 2006. New light on the Black Death: the cosmic connection. Tempus Publishing Ltd, Stroud, $224 \mathrm{p}$.

BAILLIE, M. 2007. The case for significant numbers of extraterrestrial impacts through the late Holocene. Journal of Quaternary Science, 22, pp. 101-109.

BlaKeslee, S. 2006. Ancient crash, epic wave. New York Times, $14^{\text {th }}$ November. URL <http://www.nytimes.com/2006/11/ 14/science/14WAVE.html>, November 2006.

Bourrouilh-Le Jan, FG, and Talandier, J. 1985. Sédimentation et fracturation de haute énergie en milieu récifal: Tsunamis, ouragans et cyclones et leurs effets sur la sédimentologie et la géomorphologie d'un atoll: Motu et hoa, à Rangiroa, Tuamotu, Pacifique SE. Marine Geology, 67, pp. 263-333.

British Geological Survey 2001. Global Seismology Re- search Group Database.URL <http://www.gsrg.nhm.ac.uk>, August 2001.

Bryant, E. A. 2001. Tsunami: the underrated hazard. Cambridge University Press, Cambridge, $320 \mathrm{p}$.

Bryant, E. A., ANd Haslett, S. K. 2003. Was the AD 1607 coastal flooding event in the Severn Estuary and Bristol Channel(UK) due to a tsunami? Archaeology in the Severn Estuary, 13 (for 2002), pp. 163-167.

Bryant, E. A., AND Haslett, S. K. 2007. Catastrophic wave erosion, Bristol Channel, United Kingdom: impact of tsunami? Journal of Geology, 115, pp. 253-269.

Bryant, E. A., AND NotT, J. 2001. Geological indicators of large tsunami in Australia. Natural Hazards, 24, pp. 231-249.

BRyant, E. A., ANd Young, R. W. 1996. Bedrock-sculpturing by tsunami, South Coast New South Wales, Australia. Journal of Geology, 104, pp. 565-582.

Bryant, E., Walsh, G., ANd Aвbott, D. 2007. Cosmogenic mega-tsunami in the Australia region: are they supported by Aboriginal and Maori legends? In Myth and Geology. Edited by, L. Piccardi and W.B. Masse. Geological Society, London, Special Publications 273, pp. 203-214.

Cremona, J. 1988. A Field Atlas of the Seashore. Cambridge University Press, Cambridge, $100 \mathrm{p}$.

DAvison, C. 1924. A history of British earthquakes. Cambridge University Press, Cambridge, 416 p.

Dawson, A. G., Musson, R. M. W., Foster, I. D. L., AND BRUNSDEN, D. 2000. Abnormal historic sea-surface fluctuations, SW England. Marine Geology, 170, pp. 59-68.

Devoy, R. J. N. 2000. Implications of accelerated sea-level rise (ASLR) for Ireland. Proceedings of SURVAS Expert Workshop on European Vulnerability and Adaptation to Impacts of Accelerated Sea-Level Rise (ASLR), Hamburg, $19^{\text {th }}-21^{\text {st }}$ June 2000, pp. 52-66.

Foster, I. D. L., Albon, A. J., Bardell, K. M., Fletcher, J. L., Jardine, T. C., Mothers, R. J., Pritchard, M. A., AND TuRNER, S. E. 1991. High energy coastal sedimentary deposits: an evaluation of depositional processes in southwest England. Earth Surface Processes and Landforms, 16, pp. 341-356.

Hansom, J. D. 2001. Coastal sensitivity to environmental change: a view from the beach. Catena, 42, pp. 291-305.

Haslett, S. K. 2000. Coastal Systems. Routledge, London, $240 \mathrm{p}$.

Haslett, S. K., ANd Bryant, E. A. 2005. The AD 1607 coastal flood in the Bristol Channel and Severn Estuary: historical records from Devon and Cornwall(UK). Archaeology in the Severn Estuary, 15 (for 2004), pp. 81-89.

Haslett, S. K., AND BRyAnt, E. A. 2007. Reconnaissance of historic (post-AD 1000) high-energy deposits along the Atlantic coasts of southwest Britain, Ireland and Brittany, France. Marine Geology, 242, pp. 207-220.

Haslett, S. K., ANd CuRR, R. H. F. 1998. Coastal rock platforms and Quaternary sea-levels in the Baie d'Audierne, Brittany, France. Zeitschrift für Geomorphologie, 42, pp. 507-515. 
Heezen, B.C., And EwIng, M. 1952. Turbidity currents and submarine slumps, and the 1929 Grand Banks earthquake. American Journal of Science, 250, pp. 849-873.

Ingram, J. 1823. The Anglo-Saxon Chronicle. World Wide School, Seattle. URL <http:/www.worldwideschool.org/ library/books/hst/english/TheAnglo-SaxonChronicle/ legalese.html>, April 2007.

Jones, B., AND HunTER, I. G. 1992. Very large boulders on the coast of Grand Cayman: the effects of giant waves on rocky coastlines. Journal of Coastal Research, 8, pp. 768-774.

KerRIDGE, D. 2005. The threat posed by tsunami to the UK. Department for Environment, Food and Rural Affairs, HMSO: London, 123 p.

Long, D., AND Wilson, C. K. 2007. A catalogue of tsunamis in the UK. Report CR/07/77, British Geological Survey, Edinburgh, 28 p.

McCafferty, P., And Baillie, M. 2005. The Celtic Gods: comets in Irish mythology. Tempus Publishing Ltd, Stroud, $224 \mathrm{p}$.

Musson, R. M. W., Neilson, G., And Burton, P. W. 1986. The 1852 November 9 Irish Sea earthquake. Geophysical Journal of the Royal Astronomical Society, Abstract No. SS32, p. 270.

Mynors, R. A. B., Thomson, R. M., And Winterbottom, M. 1998. (Editors). William of Malmesbury, Gesta regum Anglorum: the history of the English Kings, volume 1. Clarendon Press: Oxford, 879 p.

National Geophysical Data Centre 2007. Tsunami event database. URL <http:/www.ngdc.noaa.gov/nndc/struts/ form? $\mathrm{t}=101650 \& \mathrm{~s}=7 \& \mathrm{~d}=7>$, June 2007.

Notт, J. F. 1997. Extremely high-energy wave deposits inside the Great Barrier Reef, Australia: determining the cause - tsunami or tropical cyclone. Marine Geology, 141, pp. 193-207.

Notт, J. F. 2003. Waves, coastal boulder deposits and the im- portance of the pre-transport setting. Earth and Planetary Science Letters, 210, pp. 269-276.

Owen, H. W. 2000. The place-names of Wales. University of Wales Press, Wales, 103 p.

Piper, D.J.W., Cochonat, P., and Morrison, M.L. 1999. The sequence of events around the epicentre of the 1929 Grand Banks earthquake: Initiation of debris flows and turbidity current inferred from sidescan sonar. Sedimentology, 46, pp. 79-97.

Scheffers, A. 2002. Paleotsunamis in the Caribbean: Field evidences and datings from Aruba, Curaçao and Bonaire. Essener Geographische Arbeiten, 33, 181 p.

Sмiтh, B. G. 1961. British Regional Geology: North Wales. Her Majesty's Stationery Office, London, 98 p.

Smith, D. E., Shib, S., Cullingford, R. A., Dawson, A. G., Dawson, S., Firth, C. A., Foster, I. D. L., Fretwell, P. T., Haggart, B. A., Holloway, L. K., And Long, D. 2004. The Holocene Storegga Slide tsunami in the United Kingdom. Quaternary Science Reviews, 23, pp. 2291-2321.

Turbitt, T., Barker, E. J., Browitt, C. W. A., Howells, M., Marrow, P. C., Musson, R. M. W., Newmark, R. H., Redmayne, D. W., Walker, A. B., Jacob, A. W. B., Ryan, E., AND WARD, V. 1985. The North Wales earthquake of 19 July 1984. Journal of the Geological Society, London, 142, pp. 567-571.

Williams, D. M., AND Hall, A. M. 2004. Cliff-top megaclast deposits of Ireland, a record of extreme waves in the North Atlantic-storms or tsunamis? Marine Geology, 206, pp. 101-117.

Williams, G. 1973. Welsh poems: sixth century to 1600. Faber and Faber, London, $128 \mathrm{p}$.

Young, R., Bryant, E., And Price, D. M. 1996. Catastrophic wave (tsunami?) transport of boulders in southern New South Wales, Australia. Zeitschrift für Geomorphologie, 40, pp. 191-207. 